\title{
Glutathione peroxidase activity in different breeds and sexes of chickens during embryonic development up to peak of egg production
}

\author{
G.S. Farahat ${ }^{1}$, E.A. Eissa ${ }^{2}$, K. Balogh ${ }^{3,4}$ and M. Mézes ${ }^{4,5}$ \\ Fayoum University, Faculty of Agriculture, \\ ${ }^{1}$ Department of Poultry Sciences, \\ ${ }^{2}$ Department of Genetics \\ 63514 Fayoum, Egypt \\ ${ }^{3}$ University of Kaposvár, Research Group of Animal Breeding and Hygiene, \\ Faculty of Animal Science \\ H-7400 Kaposvár, Hungary \\ ${ }^{4}$ Szent István University, \\ Department of Nutrition, Faculty of Agricultural and Environmental Sciences \\ H-2103 Gödöllõ, Hungary
}

(Received 21 April 2007; revised version 17 June 2008; accepted 27 October 2008)

\begin{abstract}
Glutathione peroxidase (GSHPx) activity was investigated in the liver, red blood cells (RBC) and blood plasma (BP) of different chicken genotypes. Significant differences among genotypes and age groups were found in liver GSHPx activity during embryonic development and in day-old chickens. Breed, sex and age effects were found in RBC and BP from one day of age until peak egg production. A negative correlation was found between embryo liver GSHPx activity and egg weight $(-0.24 ; \mathrm{P} \leq 0.01)$, between RBC and BP GSHPx activity and body weight $(-0.32$ and $-0.44 ; \mathrm{P} \leq 0.01)$, and between liver and RBC GSHPx activity $(-0.54 ; \mathrm{P} \leq 0.01)$, while positive correlations were demonstrated between liver and $\mathrm{BP}(0.66 ; \mathrm{P} \leq 0.01)$ and $\mathrm{BP}$ and $\mathrm{RBC}(0.32 ; \mathrm{P} \leq 0.01)$ GSHPx activity. In conclusion, variation in GSHPx activities in different chicken breeds during development suggests that it is genetically regulated. This finding indicates that GSHPx activity may be useful in selection.
\end{abstract}

KEY WORDS: chicken, embryo, glutathione peroxidase, breed, sex

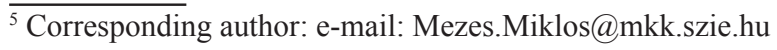




\section{INTRODUCTION}

Different reactions are required for the maintenance of metabolism and energy production in the cell, during which potentially toxic oxygen free radicals are also produced (Chester and Arthur, 1988). The body is protected against reactive oxygen metabolites by the biological antioxidant defence system, which includes antioxidant enzymes and low molecular weight antioxidants (Surai, 2002). It has been suggested that the cellular first line of antioxidant defence is based on the activity of three types of enzymes: superoxide dismutases, glutathione peroxidases (GSHPx) and catalase.

Selenium-dependent GSHPx is a key intracellular antioxidant enzyme that contains a selenocysteine residue at its active site (Handy et al., 2006). Chicken embryo tissues are characterized by high concentrations of polyunsaturated fatty acids (Noble and Cocchi, 1990) and for that reason they are sensitive to lipid peroxidation (Gaál et al., 1995); protection against lipid peroxidation is, therefore, a crucial task for embryos. A genetic variation in GSHPx activity has been suspected previously in chickens (Cunningham et al., 1987; Shen et al., 1992; Shaaban et al., 2003, 2004). Correlation between the activity of GSHPx and body weight was shown to be significant, as well. Comparison among embryonic tissues showed that the highest GSHPx activity at all stages of development was in the liver, and increased throughout embryonic development, reaching its maximum at the time of hatching (Gaál et al., 1995). Several studies have suggested that activities of GSHPx in different tissues are affected by sex. This may be the result of differences in distribution of selenium in males and females, or of metabolic differences (Finley and Kincaid, 1991). According to the free radical theory of ageing, it can be considered a process of irreversible changes associated with accumulation of free radicals induced by damage to the cell (Harman, 1956). There are also some observations about the correlation of GSHPx activity and production traits, such as body weight and weight gain in avian species (LaVronga and Combs, 1982).

The objectives of the present investigation were: a. determination of the phenotypic variation of GSHPx enzyme activity in the liver of chickens of different breeds during embryonic development up to the age of one day, b. estimation of the effects of breed, age and sex on GSHPx enzyme activity of red blood cell haemolysate (RBC) and blood plasma (BP) in different chicken breeds from the age of one day up to the age of peak egg production under standardized conditions, and c. estimation of the correlation between egg and body weight and GSHPx enzyme activity of liver, RBC and BP. 


\section{MATERIAL AND METHODS}

\section{Animals and experimental conditions}

Four chicken breeds: White Plymouth Rock (WPR), Naked Neck Plymouth (NNP) and Naked Neck New Hampshire (NNNH) and Hungarian White (HW) used in this investigation are maintained at the Institute of Small Animal Breeding and Nutrition, Gödöllo" (Hungary). All of the birds were clinically healthy and kept in the same environment and given the same diets with an average selenium content of $0.21 \mathrm{mg} / \mathrm{kg}$. Fertilized eggs were incubated at $37.8^{\circ} \mathrm{C}$ and $60 \%$ relative humidity in a forced-draught incubator with automatic egg turning.

A total of 320 eggs ( 20 of each breed on each day of incubation) was weighed and the embryos were euthanized with cooling at $-20^{\circ} \mathrm{C}$ for $5 \mathrm{~min}$ on the $14^{\text {th }}, 16^{\text {th }}$, $18^{\text {th }}$ and $20^{\text {th }}$ day of incubation. Blood and liver samples were taken and processed for sex determination or immediately frozen $\left(-20^{\circ} \mathrm{C}\right)$ until analysed.

A total of 720 blood samples (15 $\delta$ and 15 of each breed at each age) were collected on day one, and at 4, 8 and 12 weeks of age, at the age of sexual maturity (SM), laying of the first egg, and at peak egg production (highest egg production, HEP).

Egg weight (EW) and body weight (BW) were measured at the same time as the liver and blood samples were obtained.

\section{Blood and liver samples}

Blood samples were collected into tubes containing EDTA-Na ${ }_{2}(0.2 \mathrm{~mol} / \mathrm{l})$ as an anticoagulant. Freshly collected blood samples were centrifuged at 2,500 rpm, plasma was removed and stored frozen $\left(-20^{\circ} \mathrm{C}\right)$ until analysed. Erythrocytes were washed three times with a two-fold volume of physiological saline $(0.65 \% \mathrm{w} / \mathrm{v}$ $\mathrm{NaCl}$ ), then haemolysed with nine-fold of their volume of redistilled water and by freezing $\left(-20^{\circ} \mathrm{C}, 18 \mathrm{~h}\right)$ and thawing $\left(37^{\circ} \mathrm{C}, 30 \mathrm{~min}\right)$. Liver samples were homogenized before analysis with a nine-fold amount of physiological saline and the 10,000 $\mathrm{g}$ supernatant fraction was used for determination of enzyme activity.

\section{Biochemical methods}

GSHPx activity was measured using reduced glutathione and cumene-hydroperoxide as co-substrates (Lawrence and Burk, 1976) and the oxidation of reduced glutathione measured by the method of Sedlak and Lindsay (1968). Enzyme activity was expressed in units reflecting the oxidation of reduced glutathione in $\mathrm{nm}$ per min at $25^{\circ} \mathrm{C}$ and was related to protein content. The total protein 
content of $\mathrm{BP}$ and $\mathrm{RBC}$ was determined using the biuret method (Weichselbaum, 1946), while that of liver homogenate, using the Folin phenol reagent (Lowry et al., 1951). Sex determination was made in embryonic blood samples. DNA was extracted from blood samples following haemolysis and protein digestion using the salting out method. Approximately 80-100 ng DNA were taken for PCR using Dynazyme ${ }^{\circledR}$ DNA polymerase (Finnzymes, Oy, Finland) and the appropriate buffer in a total volume of $15 \mu \mathrm{l}$. A total of 26 RAPD primers of AP Biotech and Operon were tested for variable fragments. The RAPD-PCR protocol (Williams et al., 1990) was carried out in a 9700 GeneAmp thermocycler 4 min $95^{\circ} \mathrm{C}$ denaturation followed by 45 cycles of $15 \mathrm{sec}$ at $95^{\circ} \mathrm{C}, 1 \mathrm{~min}$ at $36^{\circ} \mathrm{C}$ and $1 \mathrm{~min}$ at $72^{\circ} \mathrm{C}$ extension. PCR products were separated on $1.5 \%$ agarose gel with ethidium-bromide.

\section{Statistical analysis}

Data of liver, BP and RBC GSHPx activity were subjected to analysis using three-way ANOVA with breed, age and sex as the main effects, according to the following unitrait model:

$$
\mathrm{Y}_{\mathrm{ijk} \mathrm{k}}=\mu+\mathrm{G}_{\mathrm{i}}+\mathrm{A}_{\mathrm{j}}+\mathrm{S}_{\mathrm{k}}+(\mathrm{GA})_{\mathrm{ij}}+(\mathrm{GS})_{\mathrm{ik}}+(\mathrm{AS})_{\mathrm{jk}}+(\mathrm{GAS})_{\mathrm{ijk}}+\mathrm{e}_{\mathrm{ijk} \mathrm{k}}
$$

where: $\mu$ - common mean; $G_{i}$ - effect of the $i^{\text {th }}$ breed; $A_{j}$ - effect of the $j^{\text {th }}$ age; $\mathrm{S}_{\mathrm{k}}$ - effect of the $\mathrm{k}^{\text {th }} \operatorname{sex}(\mathrm{GA})_{\mathrm{ij}}$ - effect of interaction of the $\mathrm{i}^{\text {th }}$ breed with the $\mathrm{j}^{\text {th }}$ age; (GS $)_{i k}$ - effect of interaction of the $i^{\text {th }}$ breed with the $\mathrm{k}^{\text {th }}$ sex; $(A S)_{j \mathrm{k}}$ - effect of interaction of the $\mathrm{j}^{\text {th }}$ age with $\mathrm{k}^{\text {th }} \operatorname{sex}$; (GAS $)_{\mathrm{ijk}}$ - effect of interaction of the $\mathrm{i}^{\text {th }}$ breed with the $\mathrm{j}^{\text {th }}$ age with the $\mathrm{k}^{\text {th }}$ sex; $\mathrm{e}_{\mathrm{ijkl}}$ - random error term, using the GLM procedure of SPSS program (SPSS for Windows, 1999).

Means were compared for main effects and their interaction by Duncan's multiple range test (Duncan, 1955), when significant $F$ values were obtained $(\mathrm{P}<0.05)$. Correlation analyses were performed by using the CORR procedure from SPSS (SPSS for Windows, 1999).

\section{RESULTS}

During embryonic development, the GSHPxactivity of the $10,000 \mathrm{~g}$ supernatant fraction of liver homogenates of the tested breeds differed significantly from the overall means. The highest activity was found in breed HW and the lowest, in WPR. Sex also had a significant effect on liver GSHPx activity, with females having significantly higher values than males (Table 1). Moreover, GSHPx activity significantly decreased during embryonic development up to one day of 
Table 1. Glutathione peroxidase activity in liver of embryos chicken of different genotypes, sex and age

\begin{tabular}{|c|c|c|c|c|c|c|c|c|}
\hline \multirow{3}{*}{\multicolumn{2}{|c|}{ Items }} & \multicolumn{5}{|c|}{ Glutathione peroxidase activity, U/g protein } & \multirow{3}{*}{$\begin{array}{c}\text { Overall } \\
\text { mean }\end{array}$} & \multirow{3}{*}{$\begin{array}{l}\text { Pooled } \\
\text { SEM }\end{array}$} \\
\hline & & \multicolumn{5}{|c|}{ days of incubation } & & \\
\hline & & $14^{\text {th }}$ & $16^{\text {th }}$ & $18^{\text {th }}$ & $20^{\text {th }}$ & $21^{\text {st }}$ & & \\
\hline \multicolumn{9}{|c|}{ Breed effect ${ }^{1}$} \\
\hline & WPR (ぶ) & 2.16 & 1.44 & 1.56 & 1.40 & 1.24 & 1.62 & 0.09 \\
\hline & WPR ( $(+)$ & 2.18 & 1.39 & 1.60 & 1.40 & 1.60 & 1.59 & 0.08 \\
\hline & WPR $(\hat{\jmath}++)$ & $2.17^{\mathrm{b}}$ & $1.42^{\mathrm{b}}$ & $1.58^{\mathrm{a}}$ & 1.40 & $1.42^{\mathrm{a}}$ & $1.60^{\mathrm{b}}$ & 0.04 \\
\hline & 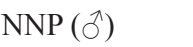 & $2.19 *$ & 1.64 & 1.36 & 1.14 & 1.23 & 1.48 & 0.10 \\
\hline & NNP (q) & 2.73 & 1.74 & 1.58 & 1.41 & 1.27 & 1.75 & 0.08 \\
\hline & $\mathrm{NNP}(ふ++)$ & $2.46^{\mathrm{ab}}$ & $1.69^{\mathrm{ab}}$ & $1.47^{\mathrm{a}}$ & 1.28 & $1.25^{\mathrm{ab}}$ & $1.64^{\mathrm{ab}}$ & 0.04 \\
\hline & NNNH (ठ゚) & $2.34 *$ & $1.49^{*}$ & $1.38^{*}$ & 1.35 & 1.04 & 1.55 & 0.08 \\
\hline & NNNH (q) & 2.86 & 2.04 & 0.85 & 1.59 & 1.26 & 1.74 & 0.09 \\
\hline & NNNH $(\lesssim++)$ & $2.60^{\mathrm{a}}$ & $1.77^{\mathrm{ab}}$ & $1.11^{\mathrm{b}}$ & 1.47 & $1.15^{\mathrm{b}}$ & $1.63^{\mathrm{ab}}$ & 0.04 \\
\hline & HW (ठ઼) & $2.21 *$ & 1.99 & 1.50 & 1.18 & 1.62 & 1.70 & 0.09 \\
\hline & HW (P) & 2.67 & 2.16 & 1.24 & 1.35 & 1.63 & 1.80 & 0.08 \\
\hline & $\mathrm{HW}(\hat{\jmath}++)$ & $2.44^{\mathrm{ab}}$ & $2.07^{\mathrm{a}}$ & $1.37^{\mathrm{ab}}$ & 1.26 & $1.63^{\mathrm{a}}$ & $1.75^{\mathrm{a}}$ & 0.04 \\
\hline \multicolumn{9}{|c|}{ Sex effect } \\
\hline & $\hat{\sigma}$ & $2.23^{y}$ & $1.64^{y}$ & 1.45 & 1.27 & 1.28 & $1.58^{y}$ & 0.03 \\
\hline & q & $2.60^{x}$ & $1.83^{x}$ & 1.32 & 1.44 & 1.44 & $1.73^{\mathrm{x}}$ & 0.03 \\
\hline & se effect & $2.42^{\mathrm{c}}$ & $1.74^{\mathrm{d}}$ & $1.38^{\mathrm{e}}$ & $1.35^{\mathrm{e}}$ & $1.36^{\mathrm{e}}$ & & \\
\hline \multicolumn{9}{|c|}{$\begin{array}{l}\text { a,beans for genotypes }(\hat{\jmath}+q) \text { with different letters within each column are significantly different } \\
\text { (breed effect) }(\mathrm{P}<0.05)\end{array}$} \\
\hline \multicolumn{9}{|c|}{$\mathrm{c,d, \textrm {e }}$ means for age with different letters within row are significant different (age effect) $(\mathrm{P}<0.05)$} \\
\hline \multirow{2}{*}{\multicolumn{9}{|c|}{$\begin{array}{l}\text { means for sex with different letters within each column are significantly different (sex effect) } \\
(\mathrm{P}<0.05) \\
\text { significant differences within the breed between males and females }(\mathrm{P}<0.05)\end{array}$}} \\
\hline & & & & & & & & \\
\hline \multicolumn{9}{|c|}{1 WPR - White Plymouth Rock; NNP - Naked Neck Plymouth; NNNH - Naked Neck New } \\
\hline
\end{tabular}

age. Breed and sex interaction showed higher GSHPx activity in females than in males in all genotypes except WPR. Breed and day of incubation interaction of GSHPx activity of liver embryo differed significantly among breeds in all age groups, but these differences were not consistent and were the highest on the $16^{\text {th }}$ day of incubation. Significant differences were obtained in age and sex interaction, where females had higher activity than males, except on the $18^{\text {th }}$ day of incubation. Breed, age and sex interaction differed significantly as shown in Table 1.

During post-hatching development, the overall mean of GSHPx activity in 
RBC of breed HW was the highest and of WPR, the lowest. Sex significantly influenced enzyme activity, with males showing higher activity than females (Table 2). Age also significantly influenced GSHPx activity in RBC. It was the

Table 2. Gluathione peroxidase activity in red blood cell haemolysates of chickens of different genotypes, sex and age

\begin{tabular}{|c|c|c|c|c|c|c|c|c|}
\hline \multirow{2}{*}{ Items } & \multicolumn{6}{|c|}{ Glutathione peroxidase activity, U/g protein } & \multirow{2}{*}{$\begin{array}{c}\text { Overall } \\
\text { mean }\end{array}$} & \multirow{2}{*}{$\begin{array}{l}\text { Pooled } \\
\text { SEM }\end{array}$} \\
\hline & 1st day & 4 weeks & 8 weeks & 12 weeks & SM & HEP & & \\
\hline \multicolumn{9}{|l|}{ Breed effect ${ }^{1}$} \\
\hline WPR $(ð)$ & 4.52 & $11.02 *$ & 8.03 & 6.21 & 6.84 & 4.55 & 6.86 & 0.20 \\
\hline WPR (o) & 4.30 & 6.66 & 8.99 & 5.73 & 5.70 & 3.68 & 5.84 & 0.20 \\
\hline WPR $(\hat{\jmath}+q)$ & $4.40^{\mathrm{b}}$ & $8.84^{\mathrm{b}}$ & $8.51^{\mathrm{b}}$ & $5.97^{\mathrm{b}}$ & $6.27^{\mathrm{b}}$ & $4.12^{\mathrm{b}}$ & $6.33^{\mathrm{b}}$ & 0.14 \\
\hline $\operatorname{NNP}(\widehat{\jmath})$ & 6.49 & $10.72 *$ & 5.68 & 5.39 & 7.01 & 4.25 & 6.5 & 0.20 \\
\hline $\mathrm{NNP}(+)$ & 5.04 & 9.34 & 5.20 & 4.42 & 7.15 & 5.24 & 6.07 & 0.20 \\
\hline $\mathrm{NNP}\left(\hat{\jmath}+{ }_{+}\right)$ & $5.77^{\mathrm{a}}$ & $10.03^{\mathrm{ab}}$ & $5.44^{\mathrm{b}}$ & $4.91^{\mathrm{b}}$ & $7.08^{\mathrm{ab}}$ & $4.74^{\mathrm{b}}$ & $6.38^{\mathrm{b}}$ & 0.14 \\
\hline NNNH (ठ゚) & 3.30 & $10.49 *$ & 7.87 & 7.77 & 6.80 & $7.45^{*}$ & 7.28 & 0.20 \\
\hline NNNH ( $(+)$ & 2.43 & 8.46 & 6.91 & 9.40 & 6.81 & 4.86 & 6.48 & 0.20 \\
\hline NNNH $(\widehat{\jmath}+\phi)$ & $2.87^{\mathrm{b}}$ & $9.48^{\mathrm{b}}$ & $7.39^{\mathrm{b}}$ & $8.59^{\mathrm{a}}$ & $6.81^{\mathrm{b}}$ & $6.15^{\mathrm{ab}}$ & $6.88^{b}$ & 0.14 \\
\hline HW (ð゚) & 3.18 & 10.13 & $9.33^{*}$ & 7.05 & 8.55 & 6.11 & $7.41 *$ & 0.20 \\
\hline HW () & 3.80 & 10.27 & 11.52 & 6.53 & 7.53 & 6.30 & 7.66 & 0.20 \\
\hline HW $(\hat{\jmath}++)$ & $3.49^{\mathrm{b}}$ & $10.20^{\mathrm{a}}$ & $10.43^{\mathrm{a}}$ & $6.79^{b}$ & $8.09^{a}$ & $6.21^{\mathrm{a}}$ & $7.53^{\mathrm{a}}$ & 0.14 \\
\hline \multicolumn{9}{|l|}{ Sex effect } \\
\hline$($ đ) & 4.37 & $10.59^{x}$ & 7.73 & 6.60 & 7.32 & 5.59 & $7.03^{x}$ & 0.10 \\
\hline ( & 3.89 & $8.68^{y}$ & 8.16 & 6.52 & 6.80 & 5.02 & $6.51^{\mathrm{y}}$ & 0.10 \\
\hline Age effect & $4.13^{\mathrm{e}}$ & $9.64^{\mathrm{c}}$ & $7.94^{\mathrm{d}}$ & $6.66^{\mathrm{d}}$ & $7.06^{\mathrm{d}}$ & $5.31^{\mathrm{e}}$ & & \\
\hline \multicolumn{9}{|c|}{$\begin{array}{l}\text { means for genotypes }(\hat{\delta}+q) \text { with different letters within each column are significantly different } \\
\text { (breed effect) }(\mathrm{P}<0.05)\end{array}$} \\
\hline \multicolumn{9}{|c|}{$\mathrm{c,d, \textrm {e }}$ means for age with different letters within row are significant different (age effect) $(\mathrm{P}<0.05)$} \\
\hline \multirow{2}{*}{\multicolumn{9}{|c|}{$\begin{array}{l}x, y \text { means for sex with different letters within each column are significantly different (sex effect) } \\
(\mathrm{P}<0.05) \\
\text { significant differences within the breed between males and females }(\mathrm{P}<0.05)\end{array}$}} \\
\hline & & & & & & & & \\
\hline \multicolumn{9}{|c|}{ SM - age at sexual maturation; HEP - age at highest egg production } \\
\hline
\end{tabular}

lowest in day-old chicks, increased up to 4 weeks of age and then decreased until the period of higher egg production. Breed and sex interaction showed higher enzyme activity in males than females in all genotypes except breed HW. There were significant differences in GSHPx activity of RBC among breeds in all age groups, but they were not consistent in different age groups. At 8 weeks of age highly significant differences were found among breeds. Age and sex 
interaction was also significant; males had higher enzyme activity than females in all age groups except at 8 weeks. Breed, age and sex interactions showed wide variations between males and females in different age groups among the tested breeds. Phenotypic variations in GSHPx activity of BP in different breeds during post-hatching development are summarized in Table 3. Concerning breed effect, WPR had the highest and NNP the lowest enzyme activity in BP.

Table 3. Gluathione peroxidase activity in blood plasma of chickens of different genotypes, sex and age

\begin{tabular}{|c|c|c|c|c|c|c|c|c|}
\hline \multirow{2}{*}{ Items } & \multicolumn{6}{|c|}{ Glutathione peroxidase activity, U/g protein } & \multirow{2}{*}{$\begin{array}{c}\text { Overall } \\
\text { mean }\end{array}$} & \multirow{2}{*}{$\begin{array}{c}\text { Pooled } \\
\text { SEM }\end{array}$} \\
\hline & 1 day & 4 weeks & 8 weeks & 12 weeks & SM & HEP & & \\
\hline \multicolumn{9}{|l|}{ Breed effect ${ }^{l}$} \\
\hline WPR (ठ) & $11.79^{*}$ & $9.42 *$ & 6.13 & $5.83^{*}$ & 7.08 & $7.02 *$ & 7.88 & 0.15 \\
\hline WPR (P) & 9.54 & 13.44 & 7.04 & 7.78 & 6.96 & 5.53 & 8.38 & 0.15 \\
\hline WPR $(\hat{\jmath}+q)$ & $10.67^{\mathrm{ab}}$ & $11.43^{\mathrm{a}}$ & $6.59^{\mathrm{b}}$ & $6.80^{\mathrm{a}}$ & $7.02^{\mathrm{a}}$ & $6.27^{\mathrm{ab}}$ & $8.13^{\mathrm{a}}$ & 0.11 \\
\hline NNP $(ð)$ & 9.38 & $8.70^{*}$ & 6.50 & 4.90 & 6.20 & 6.31 & 7.00 & 0.15 \\
\hline $\mathrm{NNP}(+)$ & 9.05 & 6.77 & 6.90 & 5.52 & 4.87 & 6.74 & 6.64 & 0.15 \\
\hline $\operatorname{NNP}\left(\jmath_{+}+\right)$ & $9.22^{\mathrm{b}}$ & $7.74^{\mathrm{b}}$ & $6.70^{\mathrm{b}}$ & $5.21^{\mathrm{b}}$ & $5.64^{\mathrm{b}}$ & $6.53^{\mathrm{ab}}$ & $6.82^{\mathrm{b}}$ & 0.11 \\
\hline NNNH (ठ゚) & $12.41 *$ & 6.93 & 7.43 & $5.74 *$ & 4.86 & 6.31 & 7.30 & 0.15 \\
\hline NNNH (ㅇ) & 10.98 & 7.75 & 7.06 & 7.30 & 4.27 & 6.85 & 7.37 & 0.15 \\
\hline $\mathrm{NNNH}(\hat{\jmath}+$ + $)$ & $11.74^{\mathrm{a}}$ & $7.39^{\mathrm{b}}$ & $7.24^{\mathrm{b}}$ & $6.52^{\mathrm{ab}}$ & $4.56^{\mathrm{b}}$ & $6.58^{\mathrm{a}}$ & $7.33^{\mathrm{ab}}$ & 0.11 \\
\hline HW (ठ̊) & 8.03 & $11.45^{*}$ & $7.41 *$ & $5.69 *$ & 5.53 & 6.04 & 7.36 & 0.15 \\
\hline HW (q) & 7.79 & 8.72 & 9.80 & 3.82 & 5.58 & 5.19 & 6.80 & 0.15 \\
\hline $\operatorname{HW}(\hat{\jmath}+q)$ & $7.91^{\mathrm{b}}$ & $10.04^{\mathrm{b}}$ & $8.60^{\mathrm{a}}$ & $4.75^{\mathrm{b}}$ & $5.55^{\mathrm{b}}$ & $5.62^{\mathrm{b}}$ & $7.08^{\mathrm{ab}}$ & 0.11 \\
\hline \multicolumn{9}{|l|}{ Sex effect } \\
\hline$(ठ)$ & $10.40^{x}$ & 9.16 & $6.87^{y}$ & 5.54 & 5.92 & 6.42 & 7.38 & 0.10 \\
\hline (ㅇ) & $9.34^{y}$ & 9.15 & $7.70^{x}$ & 6.10 & 5.42 & 6.08 & 7.30 & 0.10 \\
\hline Age effect & $9.87^{\mathrm{a}}$ & $9.15^{\mathrm{a}}$ & $7.28^{b}$ & $5.82^{\mathrm{c}}$ & $5.77^{\mathrm{c}}$ & $6.25^{\mathrm{c}}$ & & \\
\hline \multicolumn{9}{|c|}{$\begin{array}{l}\text { a,b means for genotypes }(\hat{\delta}+q) \text { with different letters within each column are significantly different } \\
\text { (breed effect) }(\mathrm{P}<0.05)\end{array}$} \\
\hline \multicolumn{9}{|c|}{$\mathrm{c}, \mathrm{d}, \mathrm{e}$ means for age with different letters within row are significant different (age effect) $(\mathrm{P}<0.05)$} \\
\hline \multicolumn{9}{|c|}{$x, y$ means for sex with different letters within each column are significantly different (sex effect) } \\
\hline \multicolumn{9}{|c|}{ * $\quad$ significant differences within the breed between males and females $(\mathrm{P}<0.05)$} \\
\hline \multicolumn{9}{|c|}{ SM - age at sexual maturation; HEP - age at highest egg production } \\
\hline
\end{tabular}

Sex affected GSHPx activity of BP; males showed higher activity than females. Regarding age effect, enzyme activity in BP decreased from hatching until the age of sexual maturation and there was a moderate increase at the age of peak egg pro- 
duction. Breed and sex interaction was significant, males in NNP and HW breeds had higher GSHPx activity in BP, and females showed higher activity in WPR and NNNH breeds (Table 3). Also, there are significant differences in enzyme activity of BP among breeds in all age groups. Variation in GSHPx activity of BP showed a fluctuating pattern between breeds as they aged. In respect of sex and age significantly higher activity was found in males as compared to females on the first day, at sexual maturity, and at peak of egg production, while females showed higher activity than males at 8 and 12 weeks of age. Breed, age and sex interaction was statistically significant. However, differences between males and females in each age group showed wide variation among breeds.

Significant differences in egg weight (Table 4) were found among the breeds during the incubation period. Breed NNP had the highest egg weight on the $14^{\text {th }}$, $18^{\text {th }}$ and $20^{\text {th }}$ days of incubation, while NNNH had the highest egg weight on the $16^{\text {th }}$ day of incubation. HW had the lowest egg weight during the whole period of incubation.

Table 4. Egg weight of chickens of different genotypes, sex and age, $g$

\begin{tabular}{|c|c|c|c|c|c|c|}
\hline \multirow{2}{*}{ Item } & \multicolumn{4}{|c|}{ Days of incubation } & \multirow{2}{*}{$\begin{array}{c}\text { Overall } \\
\text { mean }\end{array}$} & \multirow{2}{*}{$\begin{array}{c}\text { Pooled } \\
\text { SEM }\end{array}$} \\
\hline & $14^{\text {th }}$ & $16^{\text {th }}$ & $18^{\text {th }}$ & $20^{\text {th }}$ & & \\
\hline \multicolumn{7}{|l|}{ Breed effect ${ }^{1}$} \\
\hline WPR (ð) & 52.57 & 49.58 & 49.73 & 50.89 & 50.70 & 0.74 \\
\hline WPR (q) & 53.55 & 54.99 & 52.45 & 50.09 & 52.77 & 0.66 \\
\hline WPR $(\hat{\jmath}++)$ & $53.06^{\mathrm{ab}}$ & $52.29^{\mathrm{ab}}$ & $51.09^{\mathrm{ab}}$ & $50.50^{\mathrm{ab}}$ & $51.73^{\mathrm{b}}$ & 0.50 \\
\hline $\mathrm{NNP}(ठ)$ & 59.14 & 52.70 & 57.25 & 55.18 & 56.07 & 0.74 \\
\hline $\mathrm{NNP}(q)$ & 56.33 & 51.84 & 53.08 & 55.06 & 54.00 & 0.60 \\
\hline $\operatorname{NNP}(\hat{\jmath}+q)$ & $57.73^{\mathrm{a}}$ & $52.27^{\mathrm{ab}}$ & $55.17^{\mathrm{a}}$ & $55.12^{\mathrm{a}}$ & $55.07^{\mathrm{ab}}$ & 0.48 \\
\hline NNNH $(ふ)$ & 56.42 & 54.92 & 54.17 & 54.02 & 54.88 & 0.65 \\
\hline NNNH (q) & 58.30 & 54.94 & 55.30 & 52.70 & 55.31 & 0.72 \\
\hline NNNH $(\lesssim+q)$ & $57.36^{\mathrm{ab}}$ & $54.93^{\mathrm{a}}$ & $54.74^{\mathrm{ab}}$ & $53.36^{\mathrm{ab}}$ & $55.10^{\mathrm{a}}$ & 0.49 \\
\hline HW (ふ) & $48.77 *$ & 45.48 & 46.67 & 44.56 & 46.37 & 0.74 \\
\hline $\mathrm{HW}(+)$ & 42.48 & 45.28 & 45.94 & 41.66 & 43.84 & 0.65 \\
\hline $\mathrm{HW}(\hat{\jmath}++)$ & $45.62^{\mathrm{b}}$ & $45.38^{\mathrm{b}}$ & $46.31^{b}$ & $43.11^{\mathrm{b}}$ & $45.11^{\mathrm{b}}$ & 0.49 \\
\hline \multicolumn{7}{|l|}{ Sex effect } \\
\hline$\hat{0}$ & 54.23 & 50.67 & 51.96 & 51.16 & 52.00 & 0.36 \\
\hline 운 & 52.66 & 51.76 & 51.70 & 49.88 & 51.50 & 0.33 \\
\hline
\end{tabular}

a,b means for genotypes $(\hat{o}+q)$ with different letters within each column are significantly different (breed effect) $(\mathrm{P}<0.05)$

* $\quad$ ignificant differences within the breed between males and females $(\mathrm{P}<0.05)$

1 the explanation - see Table 1 
Significant differences in average body weight were found among breeds in all age groups, (Table 5) WPR had the highest BW at 4 and 12 weeks of age, SM and at the age of peak egg production; NNP had the highest at 8 weeks of age.

HW had the lowest BW in all age groups. Males had significantly higher BW than females at the age of SM and peak egg production.

Table 5. Body weight of chickens of genotypes, sex and age, $\mathrm{kg}$

\begin{tabular}{|c|c|c|c|c|c|c|c|c|}
\hline Items & 1 day & 4 weeks & 8 weeks & 12 weeks & SM & HEP & $\begin{array}{c}\text { Overall } \\
\text { mean }\end{array}$ & $\begin{array}{c}\text { Pooled } \\
\text { SEM }\end{array}$ \\
\hline \multicolumn{9}{|l|}{ Breede effect ${ }^{l}$} \\
\hline WPR (ठ) & 0.038 & 0.37 & 0.80 & 1.42 & $3.05^{*}$ & $3.38^{*}$ & 1.51 & 0.024 \\
\hline WPR (P) & 0.039 & 0.34 & 0.81 & 1.44 & 2.43 & 2.33 & 1.23 & 0.024 \\
\hline$W P R(\hat{\jmath}+q)$ & $0.039^{\mathrm{ab}}$ & $0.36^{\mathrm{a}}$ & $0.80^{\mathrm{ab}}$ & $1.43^{\mathrm{a}}$ & $2.74^{\mathrm{a}}$ & $2.85^{\mathrm{a}}$ & $1.37^{\mathrm{a}}$ & 0.017 \\
\hline $\operatorname{NNP}(\widehat{\jmath})$ & 0.038 & 0.34 & 0.90 & $1.43^{*}$ & $2.95^{*}$ & $3.30^{*}$ & 1.49 & 0.024 \\
\hline NNP (q) & 0.044 & 0.37 & 0.80 & 1.18 & 2.14 & 2.30 & 1.13 & 0.024 \\
\hline$N N P(\hat{\jmath}+q)$ & $0.042^{\mathrm{a}}$ & $0.35^{\mathrm{ab}}$ & $0.85^{\mathrm{a}}$ & $1.31^{\mathrm{ab}}$ & $2.54^{\mathrm{ab}}$ & $2.80^{\mathrm{a}}$ & $1.31^{\mathrm{b}}$ & 0.017 \\
\hline NNNH (ठ) & 0.043 & 0.35 & 0.84 & 1.17 & $3.17^{*}$ & $3.31^{*}$ & 1.48 & 0.024 \\
\hline NNNH (q) & 0.039 & 0.33 & 0.73 & 1.29 & 2.17 & 2.09 & 1.11 & 0.024 \\
\hline$N N N H(\hat{\sigma}+q)$ & $0.041^{\mathrm{ab}}$ & $0.34^{\mathrm{ab}}$ & $0.79^{\mathrm{ab}}$ & $1.23^{\mathrm{ab}}$ & $2.67^{\mathrm{ab}}$ & $2.71^{\mathrm{a}}$ & $1.29^{\mathrm{b}}$ & 0.017 \\
\hline HW (ठ゚) & 0.033 & 0.26 & 0.58 & 1.04 & $2.22^{*}$ & $2.27^{*}$ & 1.07 & 0.024 \\
\hline HW (ㅇ) & 0.035 & 0.22 & 0.61 & 0.91 & 1.76 & 1.92 & 0.91 & 0.024 \\
\hline$H W(\hat{0}+q)$ & $0.034^{\mathrm{b}}$ & $0.24^{b}$ & $0.59^{b}$ & $0.98^{\mathrm{b}}$ & $2.00^{\mathrm{b}}$ & $2.10^{\mathrm{b}}$ & $0.99^{b}$ & 0.017 \\
\hline
\end{tabular}

Sex effect

\begin{tabular}{lllllllll}
$\left(\AA^{3}\right)$ & 0.039 & 0.32 & 0.71 & 1.16 & $2.78^{\mathrm{x}}$ & $2.70^{\mathrm{x}}$ & $1.28^{*}$ & 0.012 \\
$(+)$ & 0.041 & 0.29 & 0.67 & 1.13 & $2.11^{\mathrm{y}}$ & $2.14^{\mathrm{y}}$ & 1.06 & 0.012 \\
\hline
\end{tabular}

a,b means for genotypes $(\hat{\partial}+q)$ with different letters within each column are significantly different (breed effect) $(\mathrm{P}<0.05)$

$x, y \quad$ means for sex with different letters within each column are significantly different (sex effect) $(\mathrm{P}<0.05)$

* $\quad$ significant differences within the breed between males and females $(\mathrm{P}<0.05)$

SM - age at sexual maturation; HEP - age at highest egg production

1 the explanation - see Table 1

A significant negative correlation was found between embryo liver GSHPx activity and egg weight $(-0.24 ; \mathrm{P} \leq 0.01)$ and between $\mathrm{RBC}$ and BP GSHPx activity with $\mathrm{BW}(-0.32$ and $-0.44 ; \mathrm{P} \leq 0.01)$. Also, a significant negative correlation was found between the GSHPx activity of the liver and RBC $(-0.54 ; \mathrm{P} \leq 0.01)$, while significant positive correlations were shown between enzyme activity of liver and $\mathrm{BP}(0.66 ; \mathrm{P} \leq 0.01)$ and also between $\mathrm{BP}$ and $\mathrm{RBC}(0.32 ; \mathrm{P} \leq 0.01)$. 


\section{DISCUSSION}

The objectives of the present study were to identify sources of variation in GSHPx activity, with potential use as early predictors for indirect selection that may be associated with performance traits. GSHPx activity of different tissues may be a candidate for use in indirect selection if there is high variation among breeds and is correlated with performance. An attempt was made to assess the relative importance of these factors by comparing GSHPx activity of different chicken breeds to obtain some information about the possible genetic background of the differences of the GSHPx activity in different tissues. The other purpose was to obtain information about its correlation with some production traits, age and sex under standardized conditions. Environment and diet were the same for all parent stocks, and eggs were incubated under uniform conditions. This suggests that the observed differences among breeds are genetic. Thus, the results appear to support the results of Mizuno (1984) and Shen et al. (1992), who reported breed differences in the activity of GSHPx in whole blood of chickens. There is considerable variation in GSHPx activity of different breeds and this presumably reflects differences in the metabolism of a range of different compounds. If further studies confirm genetic regulation of enzyme activity, it could be used as a selection criterion. The present results clearly indicate that the Hungarian White breed has higher enzyme activity in the liver and RBC than other breeds that are not indigenous Hungarian breeds, which supports the opinion that indigenous Hungarian breeds are more resistant to oxidative stress. It is also interesting to note that, given the tissue-specificity and breed-specific developmental profile of embryos and chicken GSHPx activity, it may be argued that genetic regulatory mechanisms may exist that are capable of modulating enzyme activity. Such regulatory elements are expected to play a vital role in offering protection against oxidative tissue damage because GSHPx plays a pivotal role in the enzymatic antioxidant defence against oxygen free radicals (Surai, 2002).

Our results indicate that females had higher liver enzyme activity than males during embryonic development and at the age of one day in all studied breeds except in WPR. Similar results were obtained with GSHPx activity in rat liver, where females had higher activity than males (Debski et al., 1992).

In general, studies of variations in GSHPx activity with ageing have shown a mixed pattern of increases and decreases that are both tissue- and species- dependent. The results of the present study show that enzyme activity decreased with age in the liver during embryonic development up until hatching, which is in disagreement with the previous finding of Gaál et al. (1995). The results of the present study also indicate that RBC GSHPx activity decreased from day one of 
age until 12 weeks of age, subsequently increasing until sexual maturity and then decreasing again to the age of peak egg production. BP enzyme activity decreased with age from one day until peak egg production. In agreement with our observations, Godin et al. (1995) reported that RBC and BP GSHPx activity decreased with age in Japanese quail.

Negative correlations were found between GSHPx activity of liver and egg weight, and also between BP and RBC. The negative correlations between production traits and GSHPx activity in BP, RBC and liver that were obtained in the present experiment are similar to the results reported by LaVronga and Combs (1982). Significant negative correlations between production traits and GSHPx activity in BP, RBC and liver may represent an adaptation mechanism to relatively low selenium intake, particularly in animals with high growth rates, but further research is needed to prove that hypothesis.

The significant correlations among liver, RBC and BP GSHPx activity indicate that measurement of enzyme activity in one tissue can be used as a useful indicator for enzyme activity in other tissues. However, further research is needed to prove this hypothesis.

\section{CONCLUSIONS}

In conclusion, the existence of genetic variation in GSHPx activities in different chicken breeds during all stages of development suggests that GSHPx activity is genetically regulated. This finding indicates that GSHPx activity of different tissues may be a candidate for use in selection to improve performance and resistance against oxidative stress.

\section{REFERENCES}

Chester J.K., Arthur J.R., 1988. Early biochemical defects caused by dietary trace elements deficiencies. Nutr. Res. Rev. 1, 39-56

Cunningham D.L., Combs G.F., Saroka J.A., LaVorgna M.W., 1987. Response to divergent selection for early growth of chickens fed a diet deficient in selenium. Poultry Sci. 66, 209-214

Debski B., Zarski T., Milner J., 1992. The influence of age and sex on selenium distribution and glutathione peroxidase activity in plasma and erythrocytes of selenium adequate and supplemented rats. J. Physiol. Pharmacol. 3, 299-306

Duncan D.B., 1955. The multiple range and multiple F test. Biometrics 11, 1-42

Finley J.W., Kincaid R.L., 1991. Effect of sex and time of sampling on selenium and glutathione peroxidase activity in tissues of mature rats. Biol. Tr. Elem. Res. 29, 181-191

Gaál T., Mézes M., Noble R.C., Dixon J., Speake B.K., 1995. Development of antioxidant capacity in tissues of the chick embryo. Comp. Biochem. Physiol. Pt. B 112, 711-716 
Godin D., Garnett M., Cheng K., Nichols C., 1995. Sex-related alterations in antioxidant status and susceptibility to atherosclerosis in Japanese quail. Can. J. Cardiol. 10, 945-951

Handy D.E., Hang G., Scolaro J., Metes N., Razaq N., Yang Y., Loscalzo J., 2006. Aminoglycosides decrease glutathione peroxidase-1 activity by interfering with selenocysteine incorporation. J. Biol. Chem. 281, 3382-3388

Harman D., 1956. Aging: a theory based on free radical and radiation chemistry. J. Gerontol. 11, 298-300

Lawrence R.A., Burk R.F., 1976. Glutathione peroxidase activity in selenium deficient rat liver. Biochem. Biophys. Res. Commun. 71, 952-956

LaVronga M.W., Combs G.F., 1982. Evidence of a hereditary factor affecting the chick's response to uncomplicated selenium deficiency. Poultry Sci. 62, 164-168

Lowry D.H., Rosenbrough N.J., Farr A.L., Randall A.J., 1951. Protein measurement with the Folin phenol reagent. J. Biol. Chem. 193, 265-272

Mizuno Y., 1984. Changes in superoxide dismutase, catalase, glutathione peroxidase, and glutathione reductase activity and thiobarbituric acid-reactive products levels in early stages of development in dystrophic chickens. Exp. Neurol. 84, 58-73

Noble R.C., Cocchi M., 1990. Lipid metabolism in the neonatal chicken. Prog. Lipid Res. 29, 107140

Sedlak J., Lindsay R.H.C., 1968. Estimation of total, protein-bound and non-protein sulfhydryl groups in tissue with Ellmann's reagent. Anal. Biochem. 25, 192-205

Shaaban G., Mézes M., Hidas A., 2003. Phenotypic variation of glutathione peroxidase activity in different genotypes of different age groups of chicken and its correlation with some production traits. Arch. Geflügelk. 67, 217-224

Shaaban G., Mézes M., Hidas A., 2004. Phenotypic variation in the activities of glutathione peroxidase and their correlation with some production traits in two chicken breeds and their crosses. Arch. Geflügelk. 68, 211-217

Shen Y., Engberg R., Jakobsen K., 1992. On the requirement of vitamin E in fast and slow growing chickens experiments with broiler and Leghorn type chickens. J. Anim. Physiol. Anim. Nutr. 67, 113-122

SPSS for Windows, 1999. Version 9, SPSS Inc.

Surai P.F., 2002. Natural Antioxidants in Avian Nutrition and Reproduction. Nottingham University Press, Nottingham, pp. 615

Weichselbaum T.E., 1946. An accurate and rapid method for the determination of protein in small amounts of serum and plasma. Amer. J. Clin. Pathol. 16, 40-43

Williams J.G., Kubelik R.A., Livak K.J., Rafalski J.A., Tingey S.V., 1990. DNA polymorphisms amplified by arbitrary primers are useful as genetic markers. Nucl. Acid. Res. 18, 6531-6534 